\title{
Calvin and the Ecclesiastical Power of Jurisdiction
}

\author{
Marta García-Alonso \\ Universidad Nacional de Educación a Distancia (Humanidades), Madrid \\ mgalonso@fsof.uned.es
}

\begin{abstract}
This study offers a hypothesis that the two marks of the Church in the Calvinist Reformed tradition, together with its disciplinary power, restare the twin classical powers granted to the Church in Catholic tradition, namely the powers of order and jurisdicrion. Unlike Luther, for whom the chief ecclesiastical power was the authority to preach and teach, Calvin not only acknowledges the teaching and sacramental functions of the Church, but also stressed a jurisdictional power (jurisdictio fori) with autonomous legislative and judicial comperence. This jurisdictional dimension is the key to explaining the role played by Geneva-inspired Reformed churches vis-à-vis the State and differences from other other Protestant traditions.
\end{abstract}

Keywords: Church-State relations, ecclesiastical jurisdiction, Calvin, law, ecclesiology.

For centuries, in some versions of Catholic doctrine, the State's subordination to the Church and the absorption of civil law into the supernatural justice of the 'City of God' was asserted. Over time, the theological dispute about Church justice and the State slowly took on a more legal dimension. This helped create the doctrine of papal power. According to some medieval theorists, the emperor had an exclusively ministerial role in the Christian community: his main function was to serve the Church and watch over it to see that peace was maintained, this being the only way to ensure the tranquillity of the State. According to this doctrine, the Pope, not the Emperor, 
held universal power and was the source of all law, in virtue of the position he occupied as the head of all Christianity, being the 'vicar of Christ.' Thus, the power to bind and loose (Matt. 16.18-19), which by tradition the popes receive from Christ through Peter, became through the work of canonists and theologians a doctrine of universal papal power that enabled the papacy to make laws, to adjudicate, and to depose emperors.'

Only in view of this legal-theological framework can we appreciate Luther's originality and explain the rupture brought about by the Reformation. The Lutheran theses question the totality of ecclesiastical power. First, his doctrine substitutes potestas ordinis. This gives authorization to administer the sacraments to the faithful on behalf of the universal priesthood. Secondly, Luther considers any jurisdictional power that authorizes the Church to legislate, judge, and manage the faithful in their 'heart of hearts' to be unjustifiable. However, in his clash with the institutional Church, Luther helped weaken the ecclesiastical institution to the extent that pastors often found themselves with little authority to confront the ever-increasing prerogatives the civil authorities arrogated to themselves in ecclesiastical matrers.

It was Calvin chiefly who managed to balance the critique of papal plenitudo potestatis with the demand for some degree of jurisdiction for a church which, in this way, reclaimed its institutional dimension. The practical implications of this apparent regression were no less important: while Lutheranism ended up accepting the State's judicial supremacy, Calvinism tried to maintain a balance, if always unstable, between the ecclesiastical and political institutions and their respective legal regulations. Recovering ecclesiastical power allowed Reformed church communities of a Calvinist stamp to take on a proactive role alongside the State and helps explain the eventual difference between the Lutheran and Calvinist models of Church-State relations.

In this article, we will analyze the way Calvin progressively abandons the Lutheran doctrine of the Church in favour of an institutional Church that reasserts part of its old powers. In particular, we will see how the notion of ecclesiastical power, initiated in the third edition of the Institutes of the Christian Religion, incorporates legislative competence, while broadening the Church's doctrinal and disciplinary scope, and establishing it with precision. Advanced here is the following hypothesis: on the one hand, Calvin

1. According to Mayali, the originality of the medieval jurists consisted specifically in this fictio iuris, the definition of a legal system with universal pretensions. Cf. Laurent Mayali, "'One senses it or one does not", review of H. Berman, Law and Revolution I, in Rechtshistorisches Journal 10 (1991): 83. Many thanks to the author for sending me this text. 
accepred the Lutheran transformation of the Catholic power of order into the two marks now acknowledged as signs of the true Church; on the other hand he restated in his doctrine on Church discipline the Catholic power of jurisdiction. This latter power, the actual power of governance, is legislative and judicial (or coercive). The intention in the final part of this article is to explain what these powers consist of and how they are linked to the marks of a Reformed Church and Calvin's ideas on Church discipline. He hardly mentions his sources in this respect, so that one cannot easily provide textual evidence to prove a hypothesis about his intellectual indebredness. However, one may make plausible the claim that there are parallels between his ideas and those of some medieval predecessors.

\section{Calvin and His Early Ecclesiology}

On 21 May, 1536, Geneva adopted the Reformation in what William Naphy claims was more of a patriotic statement than an act of faith. ${ }^{2}$ Soon afterwards, the Republic of Geneva was constituted. These two events destroyed the very foundations of the former temporal and spiritual power of the bishop in the city. Thereby, modelled on Swiss cities, all the episcopal functions were transferred to the civil power, including the functions regarding the new church's ecclesiastical organization. Accordingly, although the city's first Reformer, William Farel, had been preaching in Geneva since 1532, he had not managed to establish an ecclesiastical organization capable of participating in decision-making about morality and customs in the city, issues now exclusively appropriated by the secular power. Faced with such an ecclesiastical model, Calvin settled in Geneva in July 1536 at Farel's request, equipped with the first edition of Christianae religionis institutio. ${ }^{3}$

In these Institutes, dedicated to Francis I, Calvin intended to reconstruct the ecclesiological bases of the 'people of God.' His main principle is the definition of the Church as the 'community of the chosen people' or the 'invisible Church,' made up of those who are part of the group pre-elected to salvation. Ecclesiastical jurisdiction is a concept that barely exists in the first edition, which clearly shows a Lutheran influence: the power of the keys is limited to preaching and the sacraments, the latter being confined to baptism

2. He even maintains that this was the true cause of Genevan anti-Catholicism. Cf. William Naphy, Calvin and the Consolidation of the Genevan Reformation (Manchester and New York: Manchester University Press, 1994), 19.

3. This Latin editio princeps (Basel, 1536) was not translated into French. See, however, n. 7 below. 
and the Eucharist. ${ }^{4}$

However, Luther was not the only formative influence on Calvin during this period. From his sojourn in Basel, his refuge after fleeing France, his native country, he had learned both the need to implant ecclesiastical discipline (including excommunication) and the inappropriateness of allowing the political power to assume these functions. ${ }^{5}$ The first measures taken by Farel and Calvin in Geneva are a good example of the influence of these principles. The Reformers successively presented a series of documents to the Genevan magistrature for approval, documents which claim the control of discipline and doctrine for the new church in different ways. These are the 'Articles,' the 'Catechism,' and the 'Confession of Faith.' Even though the Church defined itself theologically as an invisible community of the elect, Calvin realized that it was necessary to constitute practical norms in the congregation of the faithful because (in opposition to what the Anabaptists believed), he held that a community of pure Christians was not possible in the world. Proof of this is his insistence, after the Confession of Faith, on drafting 'Ordinances' to guarantee peace and order in the church community. In the same way, if only discreetly, he had maintained in the 1536 edition of Institutes a need for a certain order in the Church, without which it would be doomed to disintegrate like any human organization.

However, the city of Geneva had adopted the ecclesiastical model of Bern: the civil power held all the former episcopal prerogatives on ecclesiastical matters and it was not prepared to relinquish them so easily. Yet it was not just the Genevan Council, but also the citizens themselves who refused to submit once again to the pretensions of the church, even though it was no longer a Catholic church. Many Genevan citizens did not attend the public profession of faith that the Articles required ${ }^{7}$ and they refused to accept the

4. Cf. Johannes Plomp, De kerkelijke Tucht bij Calvijn (NV Kampen: J.H.Kok, 1969), 14-23 (Luther and Melanchthon).

5. According to Kuhr, both doctrines appear in the theology of the Basel Reformer, Johannes Oecolampadius (1482-1531). Cf. Olaf Kuhr, 'Calvin and Basel: The significance of Oecolampadius and the Basel Discipline Ordinance for the Institution of Ecclesiastical Discipline in Geneva,' Scottish Bulletin of Evangelical Theology 16 (1998): 19-33. Many thanks to the author for his kindness in sending us a copy of the article.

6. Articles (CO 10, 5-14); Catéchisme (CO 22, 33-74); Confession de la foy (CO 22, 85-96). 'CO' = Joannes Calvini opera quae supersunt omnia (Guilielmus Baum, Eduardus Cunitz, Eduardus Reuss (eds), 59 vols (Braunschweig: Schwetschke and Sons, 1863-1900).

7. Arricle 1: CO 10, 11-12. 
new ecclesiastical legislation.

The struggle to recover the ecclesiastical powers was a constant in the Reformer's activity and was constantly spurred by the political circumstances of a city which did not cease to resist aspects of his reforms. Both Calvin's first Genevan ministry and his exile in Strasbourg were decisive in granting the visible church community a more important place in the next edition of the Institutes. As we shall see, strengthening the theoretical bases of the Church as a visible institution made it easier to convert doctrine into concrete judicial measures, such as the preparation of the 'Ecclesiastical Ordinances.'

\section{Discipline as an Ecclesiastical Power}

Expelled from Geneva in 1538, Calvin sought refuge in Strasbourg, where Bucer had introduced the Reformation in the 1520s. In 1539, Calvin wrote the second version of Institutes there, revising and extending his ecclesiology. ${ }^{8}$ In this version, the concept of the visible Church takes on a profile that it lacked in the first edition. For Calvin warns that the links that unite the community of the elect in the Church depend not only on preaching the Word and administering the sacraments, ${ }^{\text {? }}$ but also on preserving a concrete institutional dimension. For this, the Church itself is responsible, because maintaining 'order' is the conditio sine qua non for the existence of any human association. ${ }^{10}$ Oecolampadius' work in Basel had shown him the importance of church discipline, and after his sojourn with Bucer in Strasbourg, Calvin intermittently incorporates discipline as a third nota defining the Church." It was not, however, Strasbourg but Geneva that gave Calvin the chance to develop the practical consequences of this new definition. Debate with Sadoleto provided a further motive.

In fact, taking advantage of the confusion in the Genevan Church after Calvin and Farel had left, Cardinal lacopo Sadoleto tried to get the people

8. This second version not only revised the previous one but also extended the six original chapters of the 1536 Institutes to seventeen. It was published initially in Latin in 1539 followed by a French version in 1541 . Millet has recently published a critical edition that we will cite as IRC 1541 , citing chapter, paragraph $(\$)$, and then the page numbers of his edition. See Olivier Millet (ed.), Institution de la Religion Chrétienne (Genève: Droz, 2008).

9. Both are fixed as the two main marks of the true church: without these notes, a reformed community is simply not possible, because without public signs, there is no ecclesiastical structure. See IRC 1541, IV, $\$ 279$, pp. 674-675. See also $\$ \$ 280,676$.

10. IRC 1541, XV, \$749, p. 1562.

11. See Plomp, De kerkelijke Tucht, 30-44 (many primary sources cited there). 
to revolt against the new church in 1539 , with a letter exhorting them to go back to their former Catholic faith and submit to the Pope. ${ }^{12}$ In order to defend their doctrinal and political independence the Genevans went to the Bernese who, in turn, asked Calvin to write an answer to the cardinal. Despite being in exile, Calvin accepted and reminded the Sadoleto that Geneva, far from distancing itself from the true principles of the "Church of Christ,' which had been eclipsed by Rome, was recovering them. At this time, he used three marks to define this original Church: 'doctrine,' 'discipline,' and 'sacraments." ${ }^{13}$ So while Calvin had pointed out a month earlier in the Institutes that discipline was part of ecclesiastical jurisdiction, ${ }^{14}$ he now simply incorporated it as the 'third sign or mark of the true Church.' Thanks to discipline, the Church would be able to maintain order by purging itself of those members who did not follow its moral and doctrinal rules. Thus, Calvin, as Ganoczy has said, became 'Bucerian' while remaining Lutheran. ${ }^{15}$

However, unlike Calvin, Martin Bucer gave precedence to the disciplinary function of political authority. According to the Strasbourg reformer, it was the civil authority's duty to transform legislation in a way that was favorable to the new faith, giving it the necessary means to develop. Nevertheless, it was not a new doctrine. Its principles had been presented years earlier by the Lutheran jurist, Johannes Eisermann, who defended the role of law as an instrument in the religious Reformation. Laws should serve to lead the city more closely to Christ's kingdom, bringing its citizens to the condition of membership of Christ's kingdom. Like Bucer, Eisermann also believed that the role of the Magistrate was essential to this task, since passing Christian laws depended on him. These norms would express the letter and the spirit of the Ten Commandments, without omitting any other Biblical expression of divine Law. ${ }^{16}$ This right granted the Bucerian magistrate the power to create

12. We have used Millet's edition of Calvin's Épitre à Sadolet, in Calvin: Oeuvres choisies (Paris: Gallimard, 1995).

13. Épitre à Sadolet (Millet edn), 83. While by then Calvin provisionally accepted discipline as the third mark of the Church, it will nor, however, feature as such in the final edition (1559) of the Latin Institutes. See Book IV.1.9.

14. IRC 1541, IV, \$276-277, pp. 671-672

15. Cf. Alexandre Ganozcy, Calvin, théologien de l'Église et du ministère (Paris: Cerf, 1964), 192.

16. On the legal works of Eisermann (c.1485-1558), founder of the Marburg school of jurisprudence, see J. Witte, Law and Protestantism: The Legal Teachings of the Lutheran Reformation (Cambridge: Cambridge University Press, 2002), 140ff. In facr, his doctrines may have influenced the 1533 and 1534 Strasbourg Ordinances by way of Bucer, as this is where it is explicitly acknowledged that the Magistrate's obligarion 
laws and regulations on religious and ecclesiastical matters. In his 'Consilium in causa Hamburgensi' of $1545,{ }^{17}$ Bucer insisted on this argument, defending the idea that all governments should pass laws and edicts, both ecclesiastical and secular, that correspond to the gospel, as well as watch over the correct organization of the true religion. ${ }^{18}$ And this is what the Magistrate did in Strasbourg: 'give voice to Biblical law.' The 1533 Synod fixed the general lines of ecclesiastical organization according to the 'gospel' and, the following year, the civil authority published a Church Order in which all the synodal measures acquired legal force. The 1533-1534 Strasbourg Order fixed the principle of the civil authority's competence in religious affairs, as well as its limits, and synchronized the various aspects: doctrine, discipline, and ecclesiastical administration. ${ }^{19}$

Calvin also played the role of Christian legislator or, to put it otherwise, theologian and jurist. Even if it is open to debate whether law or theology came first, both are inextricably linked in his own biography. ${ }^{20}$ Calvin never lost interest in law: he contributed to the regulation of the church of Geneva and collaborated in the legislation of the city as well. ${ }^{21}$ In contrast to his Ger-

to watch over doctrine involves the dury of controlling and even directing all ecclesiastical bodies. See Lorna Jane Abray, The People's Reformation: Magistrates, Clergy, and Commons in Strasbourg 1500-1598 (Oxford: Basil Blackwell; Ithaca, NY: Cornell University Press, 1985), 46-47. Also Witte, Law and Protestantism, 12, 153-154, where he highlights the analogies in the thinking of both Reformers.

17. See G. Seebass (ed.), Martin Bucer (1491-1551): Bibliographie (Gütersloh: Gütersloher Verlaghaus, 2005), no. 349.

18. On the Kirchenpfleger [church wardens], see Abray, The People's Reformation, 47-48, 71-72.

19. A detailed analysis of the 1534 and 1535 Ordinances is in François Wendel, L'Eglise de Strasbourg, sa constitution et son organisation (1532-1535) (Paris: Presses Universitaires de France, 1942), 108ff. Cf. also Abray, The People's Reformation, chap. 2. Bucer's influence on having civic legislation adapt to the gospel was not limited to Strasbourg, but was also important in the church orders of Ulm (1531), Augsburg (1537), Cassel (1539), and Cologne (1543); cf. Witte, Law and Protestantism, 189-190.

20. To be borne in mind that Calvin studied Roman and possibly canon law in Orleans and Bourges. For an evaluation of this formation, see Michael Leonard Monheit, 'Guillaume Budé, Andrea Alciato, Pierre De L'Estoilc: Renaissance Interpreters of Roman Law,' Journal of the History of Ideas 58 (1997): 21-40; also his 'Young Calvin, Textual Interpretation and Roman Law,' Bibliotheque d'Humanisme et Renaissance 59 (1997): 263-282. See further, Irena Backus, 'Calvin's Concept of Natural and Roman Law,' Calvin Theological Journal 38 (2003): 7-26. Cf. Christoph Strohm, Calvinismus und Recht (Tübingen: Mohr Siebeck, 2008), 25-38.

21. See Jean Carbonnier, 'Droit et théologie chez Calvin,' in Johannes Calvin: Akademische Feier der Universität Bern zu seinem 400. Todestag. Ansprachen von Hans Merz, 
man peers, however, Calvin strove to establish the jurisdictional power of the Church.

In this situation, as Calvin easily observed in Strasbourg, his own doctrinal enterprise could be interpreted as an attempt to recover the Church's jurisdictional authority over a person's life. That is, it once again assumed authority to judge sin and subject the transgressor to the corresponding punishment, instead of ceding this competence to the civil authorities. For Calvin, discipline is the jurisdiction ${ }^{22}$ that God has placed in the Church's hands to keep the order in the community of faith. ${ }^{23} \mathrm{Sin}$ is a disobedience to divine mandates that must be punished, and it is the Church's mission to purge the faults committed by the faithful and by the ministers, precisely because of this disciplinary authority derived from the spiritual power of the keys. As Bucer had already argued, it is necessary to separate those who lead an immoral, impious life from the community, in order to prevent the rest of the faithful from becoming contaminated. This task, Calvin adds, has both an exemplary and a corrective value: the punishment will incite the sinner to desist from his vices and return to the community, appropriately rehabilitated; and for those who observe this process it will be a lesson in avoiding sin. And in order for the Church to be able to create this disciplinary task, it needs the proper mechanisms, including excommunication, the most powerful of all. ${ }^{24}$

However, the Genevan Reformer did not stop at theorizing about the disciplinary basis; he tried to put into practice the concept that we see him advocate in his writings. The condition the Reformer put on his return to the city of Geneva was the establishment of a judicial framework to regulate the life of the Church and its ministers, a framework that would serve as the basis for controlling the conduct of the faithful. These theological ideas on discipline and ecclesiastical jurisdiction that we have been analyzing will take shape in the Ecclesiastical Ordinances (1541).

\section{Extension of the Church's Jurisdiction in the 1545 Institutes}

Calvin received the invitation to return on September 13, 1541. Encouraged by Farel and the Zurich pastors, who insisted on reminding him of Geneva's strategic importance for the Reformation due to its location between Ger-

Otto Erich Strasser [und] Jean Carbonnier, Berner Universitätsschriften, 13 (Berne: P. Haupt, 1965), 3.

22. IRC 1541, IV, \$\$ 276-277, p. 671.

23. IRC 1541, XV, \$749, p. 1562.

24. IRC 1541, IV, $\$ \$ 277-278$, pp. 672-673. 
many, France, and Italy, ${ }^{25}$ he decided to accept it, but with certain conditions: he would only return if the City Council committed itself to providing a regulated ecclesiastical constitution according to the Word of God for the city. And his petition was accepted: the General Council approved the Ordonnances ecclésiastiques, ${ }^{26}$ conceived and drafted by Calvin himself to give the Geneva Church its own organization, on November 20, 1541. It could be said that Calvin intended, above all, to regulate the discipline of the Church in order to safeguard its order and doctrinal purity. However, laying the foundations for controlling citizen morality, despite its importance for the new Church and its recently created institutions, did not allow the complete revitalization of ecclesiastical jurisdictional functions that Luther had granted to the political power. Something more was necessary, and we can find this 'something more' in the 1545 edition of the Institutes ${ }^{27}$ in which the Church, as Höpl points out, is not defined by what it should not be, in relation to the Papists and Anabaptists, but is described in positive terms. ${ }^{28}$ With reference to our analysis, one of these positive terms should be highlighted, namely the power assigned to the Church.

As we have seen, in the 1541 edition Calvin acknowledged that ecclesiastical authority was linked to preaching the Word and the disciplinary function that follows from it. Discipline was thus defined as jurisdictional power belonging to the Church, the main functions of which were corrective and preventative. Only four years later, in the eighth chapter of the 1545 Latin edition, ecclesiastical power was extended and defined more clearly. This authority now included three aspects: first, the doctrinal aspect, whose purpose is to articulate the articles of faith, as well as explain the main content of Scripture; secondly, the judicial or jurisdictional aspect, and thirdly, the legislative aspect. ${ }^{29}$ We will examine these three dimensions.

25. Cf. CO 11, 186-188, letrer of April 4, 1541.

26. Their theological source was the 1539 Institutes. The initial draft of Ordinances is in CO X, part 1, col. 15-30. We have used the edition in Registres de la Compagnie des Pasteurs de Genève au temps de Calvin, vol. 1: 1546-1553, edited by Robert M. Kingdon and Jean-François Bergier (Geneva: Droz, 1964), 1-13. The Council promulgated this version and it includes the Council's additions to Calvin's draft in order to guarantee the prerogatives of civil power in relation to ecclesiastical discipline.

27. This is the second French edition of Institutes based on the Latin edition of 1543 .

28. Cf. Harro Höpf, The Christian Polity of John Calvin (Cambridge: Cambridge University Press, 1985), 103.

29. 'Ie parle seulement de la puissance spirituelle, laquelle est propre à l'Eglise. Or icelle consiste en trois membres: assavoir en la doctrine, ou en la iurisdiction, ou en la faculté d'ordonner loix et statuts, 'IRC 1545, IV.8.1. We must remember that, until 


\section{Doctrinal Power}

In contrast to the Reformer's understanding of Catholic practice, the purpose of doctrinal power was not to create new articles of faith or to formulate theological doctrines with only dubious biblical support, but to explain divine Law, 'without adding or subtracting anything' to the doctrine stated therein by God, the only 'reacher and doctor of spiritual doctrine. ${ }^{30}$ For sixteenth-century Reformers, what we know today as 'free examination' did not mean interpreting Scripture individualistically and 'freely,' but in analyzing the match between ecclesiastical tradition, whether expressed in the form of council decrees, ecclesiastical laws, or theological doctrines, and the Bible. ${ }^{31}$ However, in contrast to what Lutheran and Bucerian doctrine maintained, Calvin returns the monopoly over authorization of doctrine to the Church, denying any inherent authority of the secular power in matters of faith, except for its participation as arbitrator in those cases in which the ecclesiastical ministers do not manage to reach an agreement, as reflected in the 1541 Ecclesiastical Ordinances. The production of the Catechism and the Confession of Faith are good examples of how this authority worked.

The original title of the Catechism was Instruction et confession de foy dont on use en l'Église de la dite ville. ${ }^{32}$ It is an exposition of the Decalogue, the Creed and the Lord's Prayer, and so a summary form of the 1536 Institutes. The Confession of Faith ${ }^{33}$ was presented to the Genevan authorities on November 10, 1536. Calvin ordered 1,500 copies of the Confession to be distributed throughout the city so that the people could become familiar with its contents. ${ }^{34}$ The purpose of some of its articles was to eliminate any traces of Anabaptism that

the eighteenth century, 'jurisdicrion' meant either the comperence to judge or the scope and limit of this power. Cf. Robert, Dictionnaire alphabétique et analogique de la langue française (Paris, Le Robert, 1985), s.v.

30. IRC 1545, IV.8, 6, 9, 10-16.

31. Cf. IRC 1545, IV.9. 8-10, on the authority of the Councils. The superiority of the authority of Scripture over the Church is explicitly asserted by Calvin throughout chapter 8 of Book IV of the 1545 IRC.

32. Catéchisme, $\mathrm{CO} 22,33-74$.

33. Confession de la foy, $\mathrm{CO} 22,85-96$.

34. Registres du Conseil [MS] vol. 30, f. 212v (April 17, 1537): 'Des articles touchant laz foys. Az estés resolus que estre venus Mons. le sindicque Pertemps, l'on doibge aller par les maisons de dizenne en dizenne et leur proposés lesd. articles et il doibge assister ung sindicque accompagnies du capitaine, le dizenier et des autres.' Quoted in Thomas A. Lambert, Preaching, Praying and Policing the Reform in Sixteenth Century Geneva (Ann Arbor, Michigan: University Microfilms International, 2000), 177, n. 51. 
could be found in Geneva and to distance the Reformers from the theories of the spiritualists. Thus, infant baptism was legitimated and, in pointing out the true 'marks' of the Church (preaching and sacraments), it accepts implicitly the existence of imperfection at the heart of ecclesiastical communities.

\section{Legislative Power}

We know that the 1539 edition of Institutes recognized the need for an ecclesiastical constitution in so far as, according to the Reformer, 'no order can be established without laws, much less ecclesiastical order.' The 1545 edition of Institutes incorporates one novelty: these laws are the fruit of the Church's 'legislative power. ${ }^{35}$ The Church itself, not civil authority, will be responsible for formulating laws to promote honesty and concord in the community of the faithful. There are two kinds of ecclesiastical laws: 'ceremonial laws,' which regulate rites and the way the sacraments should be administered, and 'disciplinary laws,' which regulate the behaviour of ministers and the people, following the Law of God. ${ }^{36}$

In other words, ecclesiastical legislative power applies divine Law to specific times and places, as well as to liturgical and disciplinary issues. It is true that ecclesiastical law should have Scripture, in a broad sense, as its point of reference and so it can be said that ecclesiastical laws are, in a way, divine. Nevertheless, in so far as they are produced by a human legislator and in particular cases adjudicate on what is shown generally in Scripture, ${ }^{37}$ they

35. These are laws determined by the Church, not the civil authority, as noted by François Wendel, Calvin: sources et évolution de sa pensée religieuse (Paris: Presses Universitaires de France, 1950), 233.

36. Le Gal suggests that if we accept the Calvinian principle that only God legislates, the governance of the Church boils down to a positive implementation of the relevant biblical mandates. This would bring us back to the legal tradition that prevailed in the Catholic Church before the Gregorian reform, according to which the mission of the ecclesiastical legislators is just to adapt the divine mandates to a given context, but never create laws as such. Cf. Patrick Le Gal, Le droit canonique dans la pensée dialectique de Jean Calvin, Studia Friburgensia, nouv. sér. 63: Secrio canonica, 3 (Fribourg, Suisse: Editions universitaires, 1984), 139. However, note that from Le Gal's Catholic standpoint, Calvin's position has the undesirable consequence of diminishing the legislative powers of the pope and the bishops. For a Protestant perspective, see Bernard Reymond, Entre la grâce et la loi: introduction au droit ecclésial protestant (Geneva: Labor et Fides, 1992). Cf. Jean-Claude Groshens, Les institutions et le régime juridique des cultes protestants (Paris: R. Pichon and R. Durand-Auzias, 1957).

37. IRC 1560, IV.10.30. See Jean-Daniel Benôt's critical edition, Institution de la religion chrestienne, 5 vols (Paris: Vrin, 1957-1963), for a discussion of the differences between 1545 and 1560 editions. However, these differences are not relevant for the 
appeal exclusively to Christians' external obedience. This is because 'God alone legislates over people's consciences,' so that no human ecclesiastical law can claim, as Canon Law did, to be necessary for salvation with the consequence that any failure to keep them turns the transgressor into a person who disobeys God and the Church. As examples of moral and ceremonial laws, one can point to those that prevented women from going out in public with their heads uncovered, or which prescribed certain burial rites. ${ }^{38}$ Included among the ordinances was the requirement to attend sermons, the prohibition on women teaching in the Church, guidelines for appropriate fasting, etc. along biblical norms.

\section{Judicial Power}

A complete chapter of the new 1545 edition $^{39}$ is devoted to ecclesiastical 'judicial power' or 'discipline.' Discipline is not analyzed here as a law or a guide by which everyone should live, that is, as if it were the 'nerves' of a body that unite and shape its members. ${ }^{40}$ On this occasion, Calvin defines discipline in relation to its function of preventing and controlling the transgression of moral and ecclesiastical norms, ${ }^{41}$ that is, as disciplinary (or penal) judicial power. The issue is that the Church needs discipline more than any other community because it is expected to be more orderly than any other human organization. The Church must, therefore, purge both the sins committed by the faithful and its ministers against its own (ceremonial and disciplinary) laws and the offences committed against the two tables of the Law. This disciplinary funcrion derives from the power of the keys, since in order to prevent the rest of the faithful from becoming contaminated, protecting

purpose of our analysis (see note 39), so we will refer directly to the final French version, which will be cited as IRC 1560 together with the standard book, chapter, and section references, following Benoît's text.

38. IRC 1560, IV.10.29.

39. Except for some paragraphs belonging to the 1541 edition and some lines added to the 1560 edition, the 50-page chapter replicates almost totally that of 1545 . In the 1560 edition, it is chapter XII, with the title: De la discipline de l'Eglise dont le principal usage est aux censures et en l'excommunication, See Benoît's critical edn., 238-264

40. IRC 1560, IV.12.1. Civil laws are described in the same way, as the nerves of the political community (IRC 1560, IV.20.14), following the metaphor that Cicero and Plato had already applied. This expression is normally used to show the importance of Calvinist discipline. Cf. Raymond Mentzer, 'Disciplina nervus ecclesiae. The Calvinist Reform of Nîmes,' Sixteenth Century Journal 18 (1987): 89-116.

41. 'La discipline donc est comme une bride pour retenir et domter ceux qui son rebelles à la doctrine [...],' IRC 1560, IV.12.1. 
the community from those who lead an immoral or impious life is indispensable. This task requires the most important instrument acknowledged by the Church for this purpose: excommunication. ${ }^{42}$

Nevertheless, the order pursued by ecclesiastical discipline is not the order required in the civil community or in domestic life. Its main objective is to contribute to creating the necessary conditions for the divine Word to be preached correctly and to be heard respectfully. That is, its objective is to maintain doctrinal orthodoxy and moral probity. And according to this, the need for discipline accompanies the need for power both to organize and to preserve the community, tackling behaviour that endangers it. However, according to Höpfl, what is fundamental is not only the need for discipline, but for this discipline to reside in ecclesiastical hands: 'not only is a censor necessary, but it must be a clerical censor. ${ }^{133}$ The relevance of this renewed disciplinary doctrine can be measured by assessing the activity of the joint civil and ecclesiastical institution created to support it: the Genevan Consistory, ${ }^{44}$ established in December 1541 following the publication of the Ecclesiastical Ordinances.

Regarding the Consistory's activity, it has been calculated that there were more than 700 excommunications in 1560 (160 for adultery, 102 for drunkenness, 66 for blasphemy, 35 for gambling, 33 for attending dances, and 27 for usury), at the high point of Church power in Geneva. ${ }^{45}$ The Consistory cases not only illustrate aspects of Genevan culture and social customs, but they also offer a detailed map of the people's piety. The Consistory was also entrusted with repressing practices and beliefs of the old faith, so that many of its interrogations dealt with people under suspicion of engaging in Catholic practices or who show little attachment to the Reformed faith. Examination about prayer, attendance at services, comprehension of preaching, knowledge of Reformed doctrines, etc. were common. It is evident that

42. IRC 1560, IV.11.1. However, in the 1541 Ecclesiastical Ordinances, the Council had already added an article to Calvin's original drafts, and which insisted on reducing ecclesiastical jurisdiction to preaching the Word. See Registres de la Compagnie des Pasteurs, vol. 1, 13.

43. Cf. Höpf, Christian Polity of John Calvin, 115.

44. There are over 21 volumes of manuscript registers in the Genevan State Archives that refer to the Consistory's activity in Calvin's time. At present, only the cases from the years 1542-1546 have been published. Cf. Robert Kingdon (dir.), Registres du Consistoire de Genève au temps de Calvin, 2 vols (Geneva: Droz, 1996-2001).

45. Cf. William Monter, 'La Réforme au quotidien,' in Pierre Chaunu (dir.), L'Aventure de la Reforme (Paris: Hermé, 1986), 245ff. 
the cases pursued by the Consistory causing the delinquent to be banned from the Eucharist can be seen as corresponding to offences condemned by the Law, namely against pure religion and against society.

Clearly, there are three ecclesiastical prerogatives envisaged by Calvin: doctrinal power, linked to the articulation of confessions of faith, catechisms, etc.; legislative power, referring to the capacity to create laws that order the liturgy and ceremonies; judicial or disciplinary power. Following this division, John Witte relates these three powers to the three uses of moral law and so points out the parallelism between doctrinal power and theological use, legal power and civil use, and penal power and pedagogic use. ${ }^{46}$ This is not an analogy that Calvin himself ever explored, but we cannot fail to acknowledge its significant heuristic value. None the less, another interpretation of Calvin's teaching on the Church as a whole is possible, something that Witte's analogy does not allow us to do.

It can be argued that what explains the foundation of the three ecclesiastical powers recognized by Calvin is not the uses of moral Law, but a recycling of the Catholic powers of order and jurisdiction. In Catholic tradition the power of order was defined as the first key, the capacity to establish the Church's doctrinal position. Whoever received the power of jurisdiction was thereby allowed to distribute the sacraments. Once deprived of its sacramental dimension by Luther, the powers of order and jurisdiction became the two marks of the Reformation churches. The former second key was transformed into the jurisdictional power that allowed the Calvinist Reformed Church to govern its flock. In effect, judicial authority for Calvin consists in maintaining order and discipline in the Church by controlling customs and their monitoring by courts created to this end. Legislative power, on the other hand, institutes the ecclesiastical way of government by creating disciplinary norms and norms of worship upon which legal authority can act. In other words, they provide for the correct way to administer the sacraments and ceremonies, as well as moral control over the lives of the people and the ministers.

46. John Witte, 'Moderate religious liberty in the theology of John Calvin,' Calvin Theological Journal 31 (1996): 395. According to Calvin, moral law can be divided in relation to its different meanings which furthermore correspond to its functions: 'accusing, polirical, and didacric.' This threefold division does not come from Luther, who only accepted two of these uses: accusing use and political use, but rather comes from his collaborator, Philip Melanchrhon. Cf. his Loci comunes rerum theologicarum seu hypotheses theologicae (1521), $190 \mathrm{ff}$. 


\section{Retrospect and Conclusion}

My hypothesis is that the jurisdictional power that Calvin claims for the Church is a restatement of this Catholic second key. Whereas Luther mostly denied such power to the Church, one can maintain that Calvin restated and incorporated it into the Reformed tradition. Parallels between Calvin's concept and the Catholic position in this respect can be shown.

Thomas Aquinas recognized two kinds of power or authority in the Church, sacramental (power of order) and jurisdictional or hierarchical authority. ${ }^{47}$ Magisterial power ${ }^{48}$ was understood to be part of this last kind of power, in so far as not all those who were consecrated could hold this power, bur only those who had hierarchical power: the power of the Church to impose an order according to which ministers administered the sacraments derived from Christ's sacramental authority, ${ }^{49}$ with the Pope's and bishops' jurisdictional authority derived from their power to rule the Church. Similarly, in his rereading of De potestate Ecclesiae ${ }^{50}$ in 1533, the Dominican, Francisco de Vitoria (1485-1546), a contemporary of Luther, accepted that the Church held the same two powers cited by Aquinas: order and jurisdiction..$^{51}$ According to Vitoria, both powers derived from positive divine law, not from natural law or from any sort of civil law ${ }^{52}$ and both were the legacy of Christ and the apostles to the Church, in the form of the pope and the bishops, ${ }^{53}$ not to the faithful as a whole, as the Protestant doctrine of the priesthood of all believers

47. Summa theologiae II-II q39 a 3 . An analysis of Catholic ecclesiastical authority in both its historical and systemaric aspects can be seen in A. de Hucrga et al., La potestad de la Iglesia: VII Semana de Derecho Canónico (Barcelona: Juan Flors, 1960). A historical study on the origins and evolution of Catholic doctrine on this is L.Villemin, Pouvoir d'ordre et pouvoir de jurisdiction (Paris: Cerf, 2003).

48. $S$ th III q12 a3.

49. $S$ th 111 q63 a6.

50. Sobre la Potestad de la Iglesia, in Teófilo Urdanoz, OP, (ed.), Obras de Francisco de Vitoria: Relecciones teológicas (Madrid: BAC, 1960), 196-409. Regarding the issue of law and rights, and on Father Urdanoz's introductions to his edirions, sec Carlos López Hernández, Ley, Evangelio y derecho en Francisco de Vitoria (Salamanca: Centro de Estudios Orientales y Ecuménicos Juan XXIII, 1981).

51. De potestate Ecclesiae prior q2 $\mathrm{n} 1$, in Obras de Francisco de Vitoria, 257.

52. De potestate Ecclesiae prior q3 s1 nn1-6, in Obras de Francisco de Vitoria, 274-279.

53. De potestate Ecclesiae secunda $\mathrm{q} 1 \mathrm{n} 4$, in Obras de Francisco de Vitoria, 359, This thesis involves a complete denial of the Marsilian conciliarist position that sees the Church as a whole as a depository of Christ's powers. 
holds. ${ }^{54}$ Power over order was linked to consecration, ${ }^{55}$ and power over jurisdiction belonged to the ecclesiastical regime governing Christians. ${ }^{56}$

The nuances or differences that Calvin introduces into this Carholic tradition are not minor. He does not accept that ecclesiastical laws involve the conscience of the faithful or that they have any relation to the Christian's salvation in light of sola fides. No legislation is admitted other than that which is Scripture based. ${ }^{57}$ Penal disciplinary law is not coercive other than in a spiritual sense, and its norms are not universal, as is the case with Catholic penal legislation. The number of ceremonies is restricted according to the reduction in the sacraments that have a very different meaning from the Catholic sacraments, and so on. However, whereas Luther only acknowledged the power linked to preaching and the administration of sacraments as the Church's authority (a restatement of the power of order, one can hold), Calvin acknowledged as well a judicial and legislative power that recovered part of the jurisdiction formerly granted to civil power in the Lutheran tradition. This can be viewed as the Calvinist legal 'counter-revolution. ${ }^{58}$

This ecclesiological model, however, was not easy to plant in the city of Geneva, as it was only imposed after severe conflicts, lasting years, against

54. De potestate Ecclesiae secunda $\mathrm{q} 2$, introduction, in Obras de Francisco de Vitoria, 375-376.

55. De potestate Ecclesiae prior q2 n2, in Obras de Francisco de Vitoria, 258-259.

56. 'The government of the Christian people belongs to jurisdiction, except for consecration and the administration of the sacraments, such as making or removing laws, excommunication, dictaring justice outside of the court of penitence, and other similar things.' De potestate Ecclesiae prior q2 n2, in Obras de Francisco de Vitoria, 258-259.

57. Calvin denies any authority for the papal Decretals: the Pope cannor be a valid source of ecclesiastical law. However, as the three columns of citations in Benoit's edition of the Institutes show, Calvin paid considerable attention to Gratian's Decree (c.1130-1140). This compilation of Canon Law enabled him to show the contradictions between the disciplinary activity of the ancient Church therein documented and the current practices of the Roman Church. See Michel Reulos, 'Le decret de Gratian chez les humanistes, les gallicans et les réformés français du XVIe siècle,' in Studia Gratiana 2 (Bolonia: Instituto Giuridico [Universita di Bologna], 1954), 679-696. Millet has traced back to its sources the influence of Canon Law in his recent edition of the 1545 Institution. See his Introduction, 14-17.

58. The nuances that Calvin introduced into Protestant legal thought are not significant enough to cause a real reversal of the Lutheran doctrine of the rwo kingdoms, which is why we have put 'counter-revolution' in quotation marks. Our study, on the other hand, is limited to the ecclesiastical sphere, so it does not affect the idea of law in general, in contrast to Berman's work that presents a general thesis on the history of Western law. Cf. Harrold Berman, Law and Revolution: The Impact of the Protestant Reformations on the Western Legal Tradition (Harvard: Belknap Press, 2004). 
the influence of Bern on the one hand, and in opposition to the party of the old Genevans, archirects of the city's political independence, on the other. Nevertheless, from 1555 onwards the Calvinist model prevailed and divine Law and Scripture, largely interpreted by Calvin, became the final instance of authority for Genevan society. Church and State were forced to accommodate to each other because, as Alain Dufour has pointed out, Geneva, which had been until then an ally of the Swiss, entered history as Calvin's city. ${ }^{59}$

\section{Bibliography}

Abray, Lorna Jane. The People's Reformation: Magistrates, Clergy, and Commons in Strasbourg. London: Basil Blackwell; Ithaca, NY: Cornell University Press, 1985.

Backus, Irena. 'Calvin's Concept of Natural and Roman Law.' Calvin Theological Journal 38 (2003): 7-26.

Berman, Harrold. Law and Revolution: The Impact of the Protestant Reformations on the Western Legal Tradition. Harvard: Belknap Press, 2004.

Calvin, Jean. Joannes Calvini opera quae supersunt omnia, edired by Guilielmus Baum, Eduardus Cunitz, Eduardus Reuss, 59 vols. Braunschweig: Schwetschke and Sons, 1863-1900.

Institution de la religion chrestienne, edired by Olivier Millet, Genève: Droz, 2008.

—. Institution de la religion chrestienne, edited by Jean-Daniel Benoî, 5 vols. Paris: Vrin, 1957-1963.

- Calvin: Euvres Choisies, edired by Olivier Miller. Paris: Gallimard, 1995.

Carbonnier, Jean. 'Droit et théologie chez Calvin.' In Johannes Calvin: Akademische Feier der Universität Bern zu seinem 400. Todestag. Ansprachen von Hans Merz, Otto Erich Strasser [und] Jean Carbonnier, 2-15. Berner Universitätsschriften, 13. Berne: P. Haupt, 1965.

' 'La religion: fondement du droir?.' Archives de philosophie du droit 38 (1993): $17-21$.

Dufour, Alain. 'Le mythe de Genève au temps de Calvin.' Revue Suisse d'Histoire 9 (1959): 498-518.

Ganoczy, Alexandre. Calvin, théologien de l'Église et du ministère. Paris: Cerf, 1964. García-Alonso, Marta. La teologia politica de Calvino. Madrid: Anthropos, 2008. Groshens, Jean-Claude. Les institutions et le régime juridique des cultes protestants. París: R. Pichon and R. Durand-Auzias, 1957.

Höpfl, Harro. The Christian Polity of John Calvin. Cambridge: Cambridge University

59. Cf. Alain Dufour, 'Le mythe de Genève au temps de Calvin,' Revue Suisse d'Histoire 9, (1959): 517. From this date onwards, according to the author, the 'myth of Geneva' was built; according to this myth, Geneva was the model historical expression of the French reformer's theology. 
Press, 1985.

Kuhr, Olaf. "Calvin and Basel: The significance of Oecolampadius and the Basel Discipline Ordinance for the Institution of Ecclesiastical Discipline in Geneva,' Scottish Bulletin of Evangelical Theology 16 (1998): 19-33.

Lambert, Thomas A. Preaching, Praying and Policing the Reform in Sixteenth Century Geneva. Ann Arbor, MI: University Microfilms International, 2000.

Le Gal, Parrick. Le droit canonique dans la pensée dialectique de Jean Calvin. Studia Friburgensia, nouv. sér. 63: Sectio canonica, 3. Fribourg, Suisse: Editions universitaires, 1984.

López Fernández, Carlos. Ley, Evangelio y Derecho canónico en Francisco de Vitoria. Salamanca: Universidad Pontificia de Salamanca, 1981.

Mayali, Laurent. ' "One senses it or one does not". Review of H. Berman, Law and Revolution I. Rechtshistorisches Journal 10 (1991): 78-83

Mentzer, Raymond. 'Disciplina nervus ecclesiae: The Calvinist Reform of Nîmes.' Sixteenth Century Journal 18 (1987): 89-116. doi:10.2307/2540632 (ed.). Sin and the Calvinists: morals control and the consistory in the Reformed tradition. Kirksville, MO: Sixteenth Century Journal Publishing, 1994.

Monheit, Michael Leonard. 'Guillaume Budé, Andrea Alciato, Pierre De L'Estoile: Renaissance Interpreters of Roman Law.' Journal of the History of Ideas 58 (1997): $21-40$. doi:10.1353/jhi.1997.0006

_. 'Young Calvin, Textual Interpretation and Roman Law.' Bibliothèque d'Humanisme et Renaissance 59 (1997): 263-82.

Müller, Denis. Jean Calvin: Puissance de Loi et limite du Pouvoir. Paris: Michalon, 2001.

Naphy, William G. Calvin and the consolidation of the Genevan Reformation. Manchester: Manchester University Press, 1994.

Plomp, Johannes. De kerkelijke Tucht bij Calvijn. NV Kampen: J.H.Kok, 1969 [includes a French summary in pages 361-372].

Registres de la Compagnie des Pasteurs de Genève au temps de Calvin, direcred by Robert M. Kingdon and Jean-François Bergier. Travaux d'Humanisme er Renaissance, 55. Geneva: Droz, 1962.

Registres $d u$ Consistoire de Genève au temps de Calvin, directed by Robert Kingdon, 2 vols. Geneva: Droz, 1996-2001.

Reulos, Michel. 'Le decret de Gratian chez les humanistes, les gallicans et les réformés français du XVIe siècle.' Studia Gratiana 2: 679-696. Bolonia: Instituto Giuridico [Universitá di Bologna], 1954.

Reymond, Bernard. Entre la grâce et la loi: introduction au droit ecclésial protestant. Geneva: Labor et Fides, 1992.

Strohm, Christoph. Calvinismus und Recht: Weltanschaulich-konfessionelle Aspekte im Werk reformierter Juristen in der Frühen Neuzeit. Spätmittelalter, Humanismus, Reformation, 42. Tübingen: Mohr Siebeck, 2008.

Villmin, L. Pouvoir d'ordre et pouvoir de juridiction. Paris: Cerf, 2003. 
Viroria, Francisco de. De potest[ate] Ecclesiae, in Obras de Francisco de Vitoria: Relecciones teológicas, edited by de Teóflo Urdanoz. Madrid: BAC, 1960.

Wendel, François. L'Eglise de Strasbourg, sa constitution et son organisation (1532-1535). Paris: Presses Universitaires de France, 1942.

Calvin: Sources et évolution de sa pensée religieuse. Paris: Presses Universitaires de France, 1950.

Witte, John. 'The Three Uses of the Law: a Protestant Source of the Purposes of Criminal Punishment?' Journal of Law and Religion 10 (1994): 433-465. doi: $10.2307 / 1051143$

. 'Moderate religious liberty in the theology of John Calvin.' Calvin Theological Journal 31 (1996): 359-403.

. Law and Protestantism: The Legal Teachings of the Lutheran Reformation. Cambridge: Cambridge University Press, 2002. 
Copyright of Reformation \& Renaissance Review: Journal of the Society for Reformation Studies is the property of Equinox Publishing Group and its content may not be copied or emailed to multiple sites or posted to a listserv without the copyright holder's express written permission. However, users may print, download, or email articles for individual use. 